\title{
Theoretical analysis of the AZ31 magnesium alloy deformation process by a modified method of angular extrusion
}

\section{Teoretyczna analiza procesu odkształcania stopu magnezu AZ31 zmodyfikowaną metodą wyciskania kątowego}

\begin{abstract}
The paper presents the results of the numerical modeling of a chosen magnesium alloy deformation process by a modified method of angular extrusion (AE). The research was made using a die with a circular cross-section, where the channels were arranged at right angles relative to each other. The modification concerned the differing values of applied unit strain obtained by changing the material enter/exit diameter ratio. The extrusion process was analyzed for several temperature-velocity variants. The aim of this work was to determine the most favorable conditions of the extrusion process that result in the most uniform stress and strain distribution in the material.
\end{abstract}

Keywords: angular extrusion, magnesium alloys, AZ31, FEM

\section{Streszczenie}

W artykule przedstawiono wyniki modelowania numerycznego procesu odkształcania wybranego stopu magnezu zmodyfikowaną metodą wyciskania kątowego. Badania przeprowadzono z zastosowaniem matrycy o przekroju okrągłym, w której kanały ułożone są względem siebie pod kątem prostym. Modyfikacja dotyczyła różnych wielkości zastosowanego odkształcenia jednostkowego uzyskanych w wyniku zmiany stosunku średnicy wejścia do średnicy wyjścia odkształcanego materiału. Proces wyciskania przeanalizowano dla kilku wariantów temperaturowo-prędkościowych. Głównym celem pracy było określenie najkorzystniejszych warunków prowadzonego procesu wyciskania w celu uzyskania najbardziej jednorodnych rozkładów naprężeń i odkształceń w materiale.

Słowa kluczowe: wyciskanie kątowe, stopy magnezu, AZ31, MES

Teresa Bajor Ph.D. Eng., Marlena Krakowiak Ph.D. Eng., Szymon Berski Ph.D. Eng.: Czestochowa University of Technology, Faculty of Production, Engineering and Materials Technology, Institute of Metal Forming and Safety Engineering; tbajor@wip.pcz.pl 


\section{Introduction}

The plastic working of magnesium alloys is complicated due to the specific arrangement of atoms in the crystallographic lattice, which is the reason for the low ductility caused by a limited number of slip planes typical of this type of material. Magnesium characterized by an HCP structure with the c/a ratio close to the ideal value causes the plastic working of magnesium alloys at room temperature difficult. Deformation is realized only by a slip in the basal plane, which offers a limited number of deformation systems. Therefore, the deformation of the AZ31 alloy is usually carried out at a temperature range of $250-350^{\circ} \mathrm{C}$, where the number of operating deformation systems is higher than at an ambient temperature, which allows the needed properties to be achieved in the deformed material [1-5].

The main aim of this work was to determine the most favorable conditions of the extrusion process for one of the magnesium alloys (AZ31) using three different shapes of die for angular extrusion (AE). Essential modification consisted of changing ratio $d_{0} / d_{\mathrm{k}}$ (the entrance diameter to the final diameter).

\section{Material and research technology}

The scope of this study concerns the numerical analysis of the influence of the extrusion rate on stress intensity and temperature distribution inside the deformed material. The material used for numerical simulations and experimental research was the AZ31 magnesium alloy (with a chemical composition as shown in Table 1).

Table 1. Chemical composition of investigated AZ31 magnesium alloy

\begin{tabular}{|c|c|c|c|c|c|c|c|c|}
\hline \multirow{2}{*}{ Alloy } & \multicolumn{7}{|c|}{ Content of elements, \% wt } \\
\cline { 2 - 9 } & Mg & Al & Mn & Nd & Sb & Zn & Fe & Si \\
\hline AZ31 & 96.284 & 2.58 & 0.12 & 0.005 & 0.017 & 0.99 & 0.002 & 0.02 \\
\hline
\end{tabular}

Determining the optimal extrusion parameters is a difficult task to realize. The influence of the billet temperature and extrusion conditions on the quality of the obtained product was investigated. A commonly used tool to simulate metal deformation processes is finite element analysis. It was used to predict metal flow and stress and strain distribution in deformed material. The process of theoretical analysis was realized based on the results of computer simulations performed by the FEM-based program Forge $2008^{\circledast}$. The simulations were preceded by mechanical tests to determine 
flow-stress curves of the investigated material [5]. The geometry of the initial material and tools was drawn in AutoCad2009 ${ }^{\circledR}$, while the mesh of finite elements was generated using the 'Preprocess' module of Forge $2008^{\circledR}$. For mesh generation, tetrahedral finite elements were used. The numerical investigations were made for a number of temperature-velocity variants aiming at selecting the right conditions of the ECAE process. However, some assumptions were made regarding, for example, the temperature of the working tools. Therefore, in each of the analyzed variants, the tools were heated to the temperature of the extrusion process.

On the basis of the plastometric tests made at the Institute of Plastic Working and Safety Engineering in Czestochowa (Poland), the coefficients of the Hansel-Spittel yield equation were determined $[5,6]$. The plasticity equation that was used is as follows:

$$
\sigma_{p}=A e^{m_{1} T} T^{m_{9}} \varepsilon^{m_{2}} e^{\frac{m_{4}}{\varepsilon}}(1+\varepsilon)^{m_{5} T} e^{m_{7} \varepsilon} \dot{\varepsilon}^{m_{3}} \dot{\varepsilon}^{m_{8} T}
$$

Where:

$A$ and $m_{1}-m_{9}-$ empirical coefficients,

$\varepsilon$ - effective strain,

$\dot{\varepsilon}$ - effective strain rate,

$T$ - temperature.

The coefficients in the equation (1) were determined using an inverse approach with the least squares method, which are as follows:

$$
\begin{gathered}
A=120, m_{1}=-0.005605, m_{2}=-0.645555, m_{3}=-0.142709, \\
m_{4}=-0.115967, m_{5}=0.001591, m_{7}=0.070869, \\
m_{8}=0.000577, m_{9}=0.194354 .
\end{gathered}
$$

Friction conditions were defined using Coulomb's model. Thermal conductivity between material and dies equals $2000 \mathrm{~W} / \mathrm{m}^{2} \mathrm{~K}$. The visco-plastic model of material flow described by the Norton-Hoff equation was used [5].

The billet (with the following dimensions: diameter of $d_{0}=15 \mathrm{~mm}$ and length of $I_{0}=100 \mathrm{~mm}$ ) was extruded through the die, with intersection angle $a=90^{\circ}$ and the deformation zone defined by fillet radius: external $(R)$ and internal $(r)$ as shown in Figure 1.

The extrusion process was realized for three variants of the AE matrix - one conventional, were $d_{0} / d_{k}=1$, and two modified. The modification of the die was based on the fact that the output horizontal channel was contracted to result in a rod with a smaller diameter, which could be used for further plastic deformation. After one pass through the contracted angular channel, the reduction coefficient equals $\lambda=1.6\left(d_{0} / d_{\mathrm{k}}=1.25\right)$ and $\lambda=2.7\left(d_{0} / d_{\mathrm{k}}=1.67\right)$, where $d_{0}$ is the input channel diameter and $d_{\mathrm{k}}$ is the output channel diameter. 


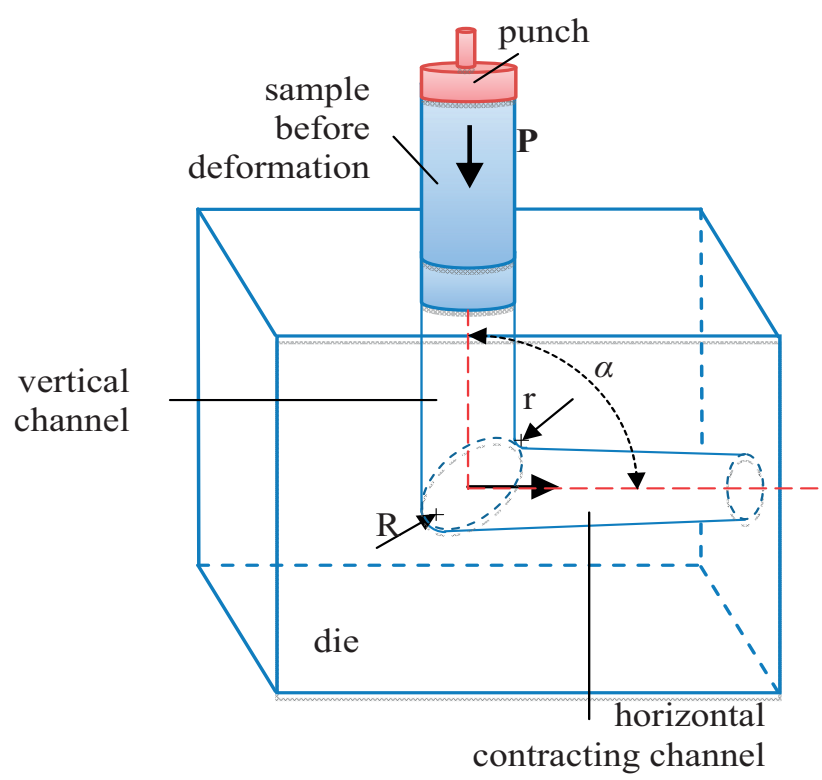

Fig. 1. Scheme of modified AE process [7]

The numerical studies were performed using several variants of temperature-velocity conditions. Three extrusion rates were used (respectively: $1 \mathrm{~mm} / \mathrm{s}, 10 \mathrm{~mm} / \mathrm{s}$, and $20 \mathrm{~mm} / \mathrm{s}$ ). In addition, three different extrusion temperatures were applied $\left(250^{\circ}, 300^{\circ}\right.$, and $\left.350^{\circ} \mathrm{C}\right)$.

\section{Analysis of the results}

The numerical analysis was made for all assumed temperature-velocity variants. The exemplary stress distributions obtained from numerical simulations observed on longitudinal cross sections in the material during the deformation process at a temperature of $250^{\circ} \mathrm{C}$ and $1 \mathrm{~mm} / \mathrm{s}$ punch feed rate for each of the investigated variants of the die are shown in Figure 2.

On the basis of the conducted analysis, it can be observed that, in each of the analyzed variants $\left(d_{0} / d_{k}\right)$, the highest value of stress occurs in the zone of material passed through the angular channel. It is necessary to draw attention to the fact that the use of modifications $\left(d_{0} / d_{\mathrm{k}}\right)$ causes an increase in normal stress in the horizontal channel for the higher value of diameter reduction. The growth of $d_{0} / d_{\mathrm{k}}$ causes an increase in the stress of the material during the approach of the calibration zone from $20 \mathrm{MPa}$ (for $d_{0} / d_{\mathrm{k}}=1$ ) up to $140 \mathrm{MPa}$ (for $d_{0} / d_{\mathrm{k}}=1.67$ ). On the basis of the values of normal stress determined from longitudinal distributions for the rest of the deformation variants, the highest values were obtained. The results for a punch feed rate of $1 \mathrm{~mm} / \mathrm{s}$ and three temperatures of investigated process are shown in Figure 3. 
a)

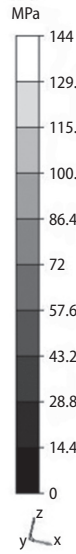

b) MPa
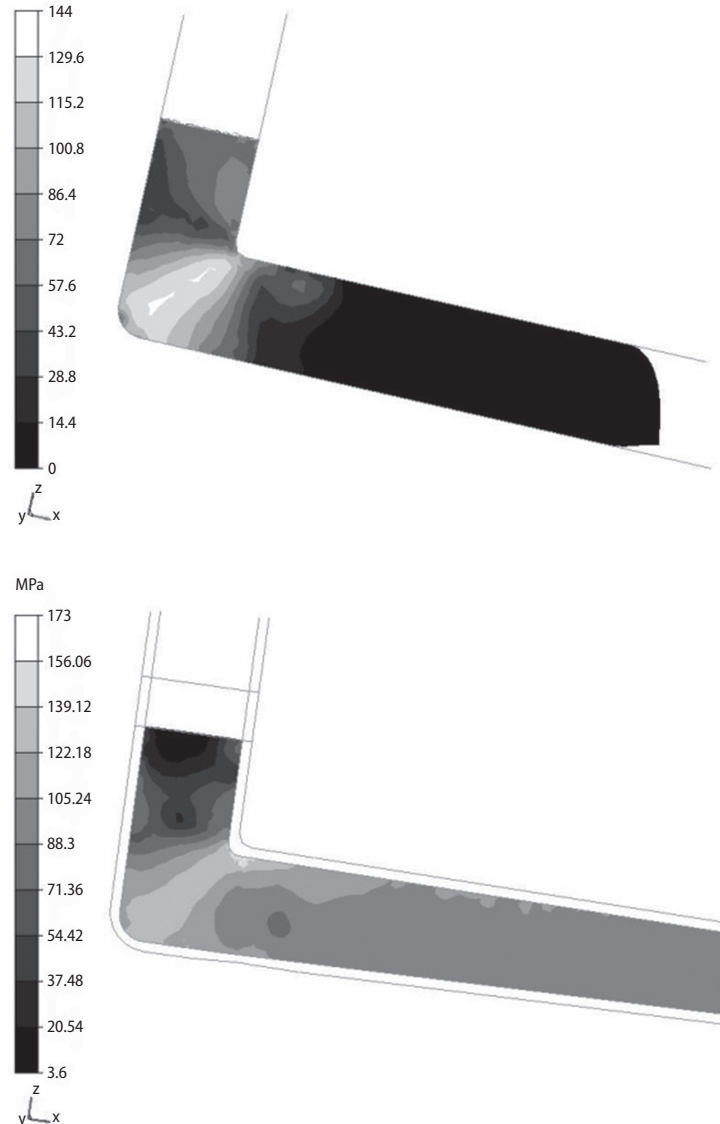

$x^{2}$

$\mathrm{MPa}$

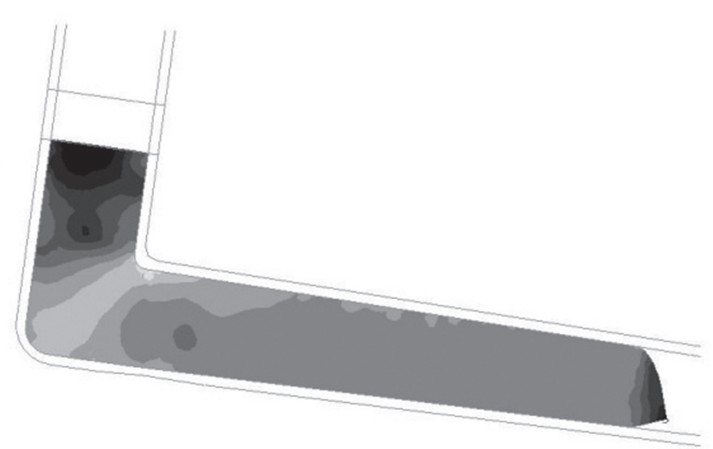

C) $\mathrm{MPa}$
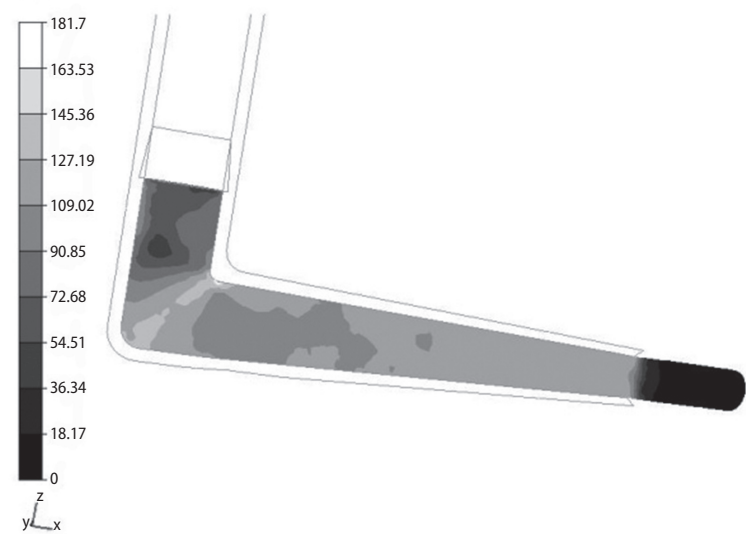

Fig. 2. Stress distribution in the material deformed in $A E$ process with punch velocity of $1 \mathrm{~mm} / \mathrm{s}$ at a temperature of $250^{\circ} \mathrm{C} ; d_{0} / d_{k}:$ a) 1 ; b) 1.25 ; c) 1.67 


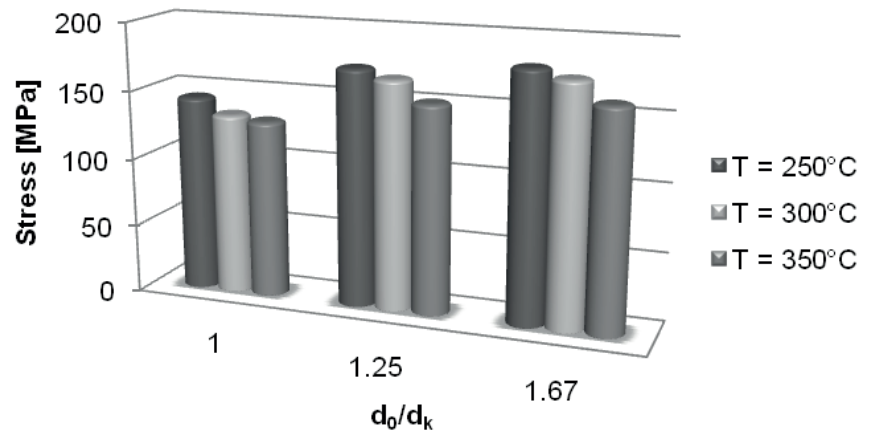

Fig. 3. Relationship between the values of stress in the material deformed in the AE process with a punch feed rate of $1 \mathrm{~mm} / \mathrm{s}$, temperature of the process, and $d_{0} / d_{k}$ ratio

The influence of the punch feed rate and temperature of the process on normal stress values for each of the analyzed variants $\left(d_{0} / d_{k}\right)$ are shown in Figure 4.

The higher extrusion rate causes an increase in stress intensity in the analyzed material. During passing through the angular channel, changes of stress concentration in the deformed specimens were observed.

a)

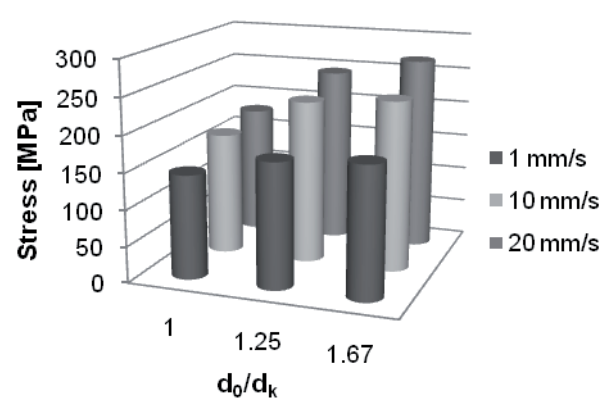

b)

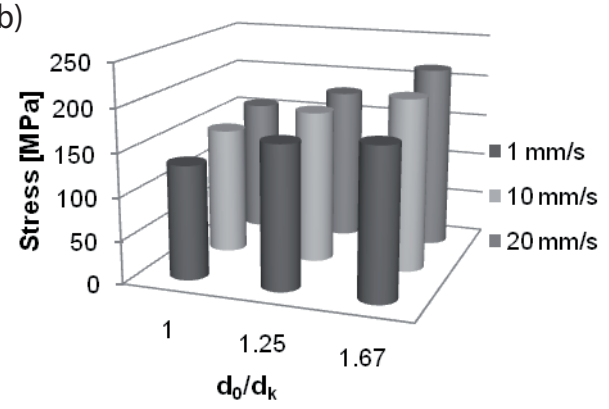

c)

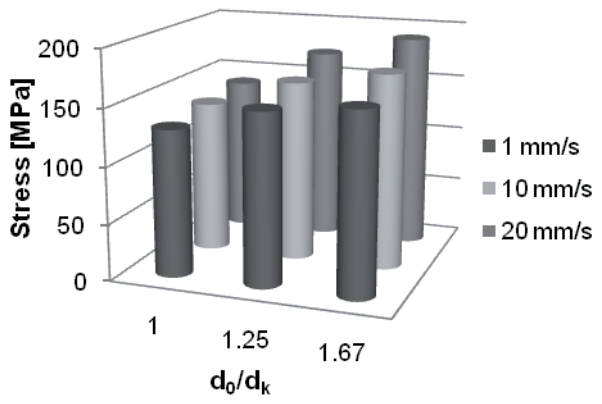

Fig. 4. Relation of maximal stress occurring in the material during deformation in the AE process depending on a punch feed rate of $1 \mathrm{~mm} / \mathrm{s}, d_{0} / d_{k}$ ratio, and temperatures of the process: a) $250^{\circ} \mathrm{C}$; b) $300^{\circ} \mathrm{C}$; C) $350^{\circ} \mathrm{C}$ 
In an analogical way, the analysis of the influence of temperature-velocity conditions and die geometry on the temperature distribution in the deformed material has been carried out. Based on numerical research, the highest values of temperature cumulated in the material during the investigated process were determined as those shown in Figures 5 and 6.

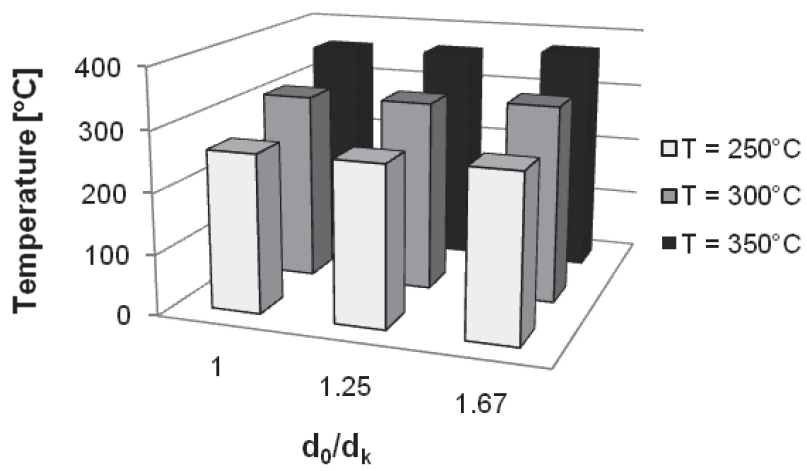

Fig. 5. Relation of temperature in the material deformed in the AE process with a punch feed rate of $1 \mathrm{~mm} / \mathrm{s}$, temperature of the process, and $d_{d} / d_{k}$ ratio

a)

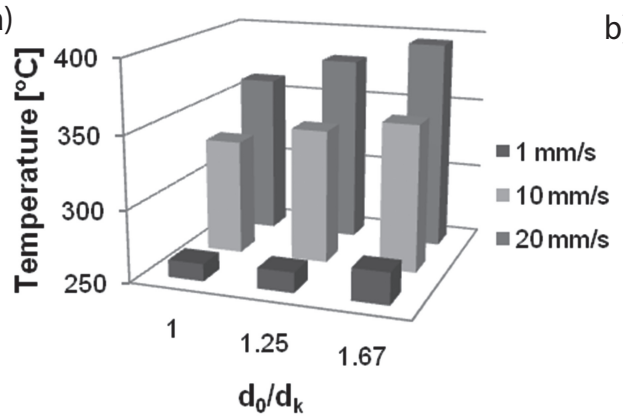

b)

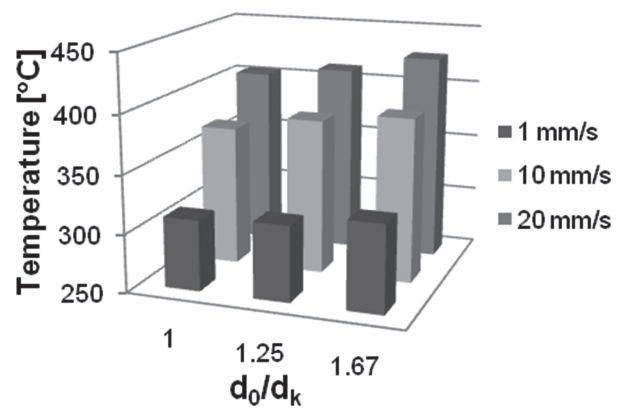

c)

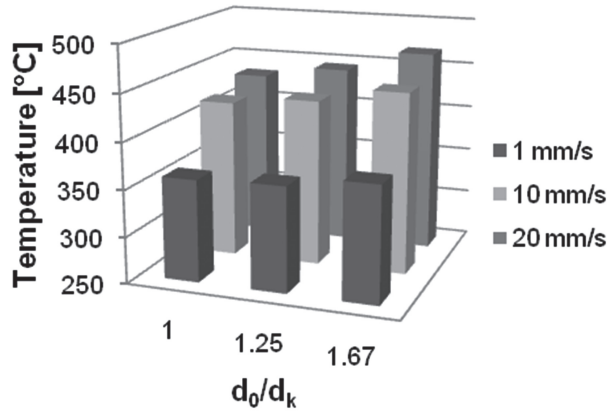

Fig. 6. Relation of maximal temperature cumulated in the material during deformation in the $A E$ process, dependent on punch feed rate, $d_{d} / d_{k}$ ratio, and temperature of deformation: a) $250^{\circ} \mathrm{C}$; b) $300^{\circ} \mathrm{C}$; C) $350^{\circ} \mathrm{C}$ 
a) $M P a$
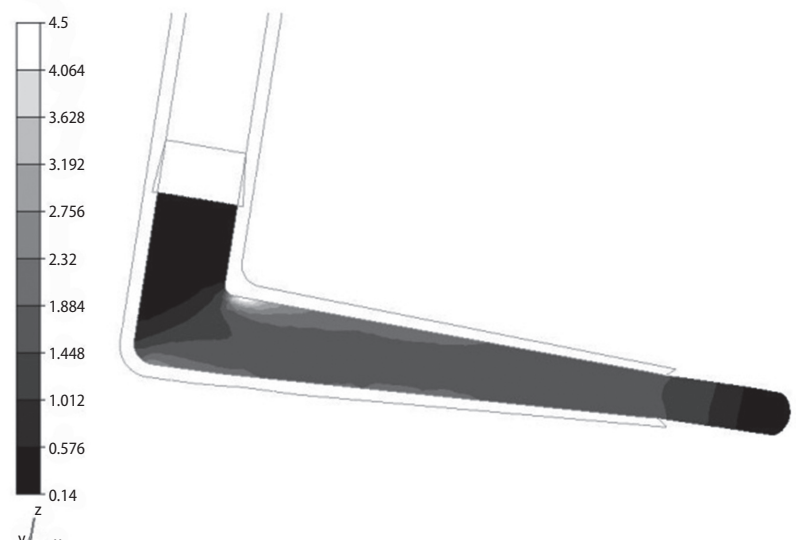

b) $\mathrm{MPa}$
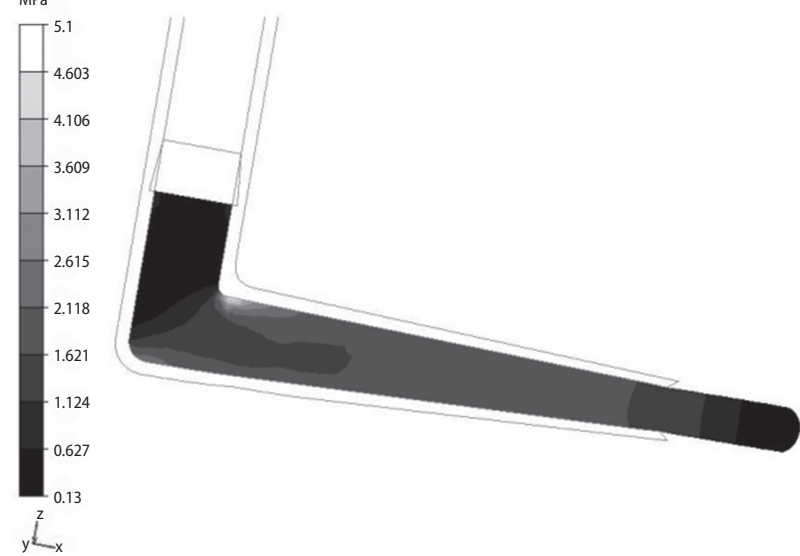

c) $\mathrm{MPa}$
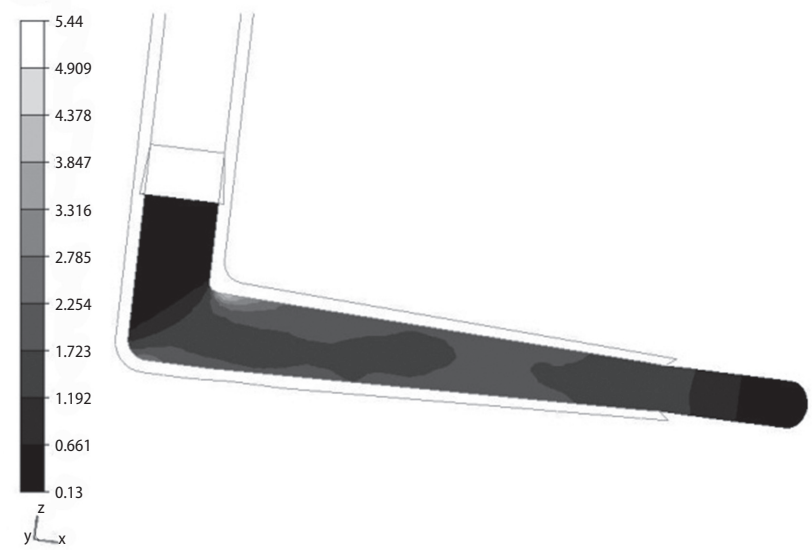

Fig. 7. Equivalent strain distribution in the material deformed in the AE process at a temperature of $300^{\circ} \mathrm{C}$ and $d_{d} / d_{k}=1.67$ for punch feed rates of: a) $1 \mathrm{~mm} / \mathrm{s} ;$ b) $\left.10 \mathrm{~mm} / \mathrm{s} ; \mathrm{c}\right) 20 \mathrm{~mm} / \mathrm{s}$ 
The influence of the punch feed rate and process temperature on the values of temperature cumulated in the material for each analyzed $\left(d_{0} / d_{\mathrm{k}}\right)$ variant is shown in Figure 6.

The last stage of the numerical research was an analysis of strain distribution during the extrusion process through the angular channel with the application of conventional and modified dies for the AE process. An exemplary relationship of changes in the values of equivalent strain occurring in the longitudinal sections for the die with the highest reduction in diameter is shown in Figure 7.

On the basis of the made analysis, we can observe that the highest cumulation of equivalent strain occurs during the passing of the material through the angular channel and the material entering to the calibration zone. An increase of the punch feed rate significantly affects the growth of equivalent strain in the material.

\section{Summary}

Based on the results of the carried-out numerical studies, it can be stated that the increase in punch feed rate causes an increase in normal stress and equivalent strain cumulated in the material at each of the analyzed geometrical and temperature variants. Increasing the extrusion velocity has a significant impact on the level of the process temperature, which is associated with energy cumulation in the deformed material. Application of a process temperature of $300^{\circ} \mathrm{C}$ and punch feed rate of $20 \mathrm{~mm} / \mathrm{s}$ allowed us to obtain a product with uniform distribution of normal stresses on the longitudinal section, and the obtained maximum value was $215.5 \mathrm{MPa}$ for the ratio $d_{0} / d_{\mathrm{k}}=1.67$.

\section{Acknowledgement}

The work was performed at the Czestochowa University of Technology in the framework of the statutory research BS/PB-201-301/2013.

\section{References}

[1] Nugmanov D.R., Islamgaliev R.K.: Structure and mechanical properties of magnesium alloy AM60V after equal channel angular pressing and rolling. Metal Science and Heat Treatment, 53, 1 (2011), 8-13

[2] Prasad Y.V.R.K., Rao K.P.: Effect of crystallographic texture on the kinetics of hot deformation of rolled Mg-3Al-1Zn alloy plate. Materials Science and Engineering A, 432 (2006), 170-177

[3] Edgar R.L.: Global overview on demand and applications for magnesium alloys. In: K.U. Kainer (ed.), Magnesium Alloys and their Applications. Wiley VCH Verlag GmbH, Weinheim, Germany, 3-8

[4] Maksoud I.A., Ahmed H., Rödel J.: Investigation of the effect of strain rate and temperature on the deformability and microstructure evolution of AZ31 magnesium alloy. Materials Science Engineering A, 504 (2009), 40-48

[5] Norton F.H.: Creep of Steels at High Temperatures. McGraw Hill Book Co., Inc., New York City, 1929

[6] Gryc A., Bajor T., Dyja H., Sawicki S., Laber K.: Physical modeling of plastic deformation conditions the rolling process of AZ31 bars in a three high skew rolling mill. Metalurgija, 53, 4 (2014), 489-492

[7] Bajor T., Krakowiak M., Szota P.: Numerical analysis of AZ61 magnesium alloy extrusion process by modified equal channel angular extrusion (ECAE) method. Metalurgija, 53, 4 (2014), 485-488 